Dr inż. Jerzy Obolewicz

Wydział Budownictwa i inżynierii Środowiska

Politechnika Białostocka

j.obolewicz@pb.edu.pl

\title{
PODSTAWY ETYKI ZAWODOWEJ UCZESTNIKÓW PROCESU \\ INWESTYCYJNEGO W BUDOWNICTWIE W ASPEKCIE BEZPIECZEŃSTWA \\ I OCHRONY ZDROWA W PRACY
}

\begin{abstract}
Streszczenie
Bezpieczeństwo i ochrona zdrowia w pracy podczas realizacji procesów inwestycyjnych w budownictwie nabiera coraz większego znaczenia. Procesy, podczas których powstają obiekty budowlane charakteryzują się wysokim poziomem zagrożeń dla zdrowia i życia uczestników biorących udział w realizacji przedsięwzięcia budowlanego. Zagrożenia te są skutkiem niewłaściwego projektowania, realizacji obiektu budowlanego i jego użytkowania, warunków pracy, dużą zmiennością warunków atmosferycznych oraz zachowań pracowników wynikających $\mathrm{z}$ obowiązujących wymagań prawa, zasad i kultury bezpieczeństwa pracy lub pominięcia zagadnień szeroko pojętego bezpieczeństwa związanego z obiektem. W artykule przedstawiono znaczenie etyki zawodowej $\mathrm{w}$ zapewnianiu i utrzymaniu właściwego poziomu bezpieczeństwa i ochrony zdrowia w życiu obiektu budowlanego.
\end{abstract}

Słowa kluczowe: budownictwo, proces inwestycyjny, etyka zawodowa, bezpieczeństwo i ochrona zdrowia

\section{ETHICS OF PARTICIPANTS INVESTMENT PROCESS IN CONSTRUCTION IN THE ASPECT OF SAFETY AND HEALTH PROTECTION AT WORK}

\footnotetext{
Summary

Safety and health protection at work during the implementation of investment processes in construction is becoming increasingly important. The processes during which construction works are created are characterized by a high level of threats to the health and life of participants taking part in the implementation of a construction project. These hazards are the result of improper design, construction of the building and its use, working conditions, high variability of weather conditions and employee behavior
} 
resulting from applicable legal requirements, principles and culture of work safety or omission of broadly understood security issues related to the object. The article presents the importance of professional ethics in ensuring and maintaining an appropriate level of safety and health in the life of a building.

Keywords: construction, investment process, professional ethics, safety and health protection

\section{Wprowadzenie}

Budownictwo można analizować biorąc pod uwagę różne jego aspekty. Budownictwo z punktu widzenia ekonomii jest ważną gałęzią przemysłu, zaspokaja bowiem podstawowe potrzeby człowieka przez dostarczanie obiektów budowlanych. Budownictwo z punktu widzenia techniki to proces realizacji przedsięwzięcia budowlanego, który obejmuje planowanie inwestycji, projektowanie obiektu budowlanego, wykonywania robót budowlanych i przekazywanie obiektu do użytki bądź do eksploatacji oraz techniczną opiekę nad utrzymaniem obiektu w stanie przydatności do użytku i eksploatacji $(2,4,6)$.

Budownictwo $\mathrm{z}$ punktu widzenia bezpieczeństwa charakteryzuje się wysokim poziomem zagrożeń dla zdrowia i życia uczestników biorących udział w realizacji przedsięwzięcia budowlanego (28). Zagrożenia te są skutkiem niewłaściwego projektowania, realizacji obiektu budowlanego i jego użytkowania, warunków pracy, dużą zmiennością warunków atmosferycznych oraz zachowań pracowników wynikających z obowiązujących wymagań prawa, zasad i kultury bezpieczeństwa pracy lub pominięcia zagadnień szeroko pojętego bezpieczeństwa związanego z obiektem $(3,17,19,20)$.

W utrzymaniu stanu bezpieczeństwa i ochrony zdrowia (stanu BIOZ)ważną rolę odgrywają wszyscy uczestnicy procesu realizacji przedsięwzięcia budowlanego. Ich wiedza naukowa i wiedza potoczna $\mathrm{z}$ obszaru techniki, ekonomiki, organizacji pracy oraz ustalone zasady bezpiecznych zachowań stanowią podstawę dobrego budownictwa $(1,5,23,24,25)$. Proces realizacji przedsięwzięcia budowlanego (inwestycji) jest formą organizacyjną obejmującą działania rozłożone w czasie, które obejmują aspekty planistyczne, projektowe, logistyczne, ekonomiczne zlokalizowane w trzech podstawowych etapach: przygotowania projektowania, wykonywania obiektu budowlanego oraz jego eksploatacji, które odgrywają znaczącą rolę w projektowaniu, utrzymaniu i kreowaniu bezpieczeństwa i ochrony zdrowia pracowników. Model realizacji przedsięwzięcia budowlanego przedstawiono na rys. 1 . 


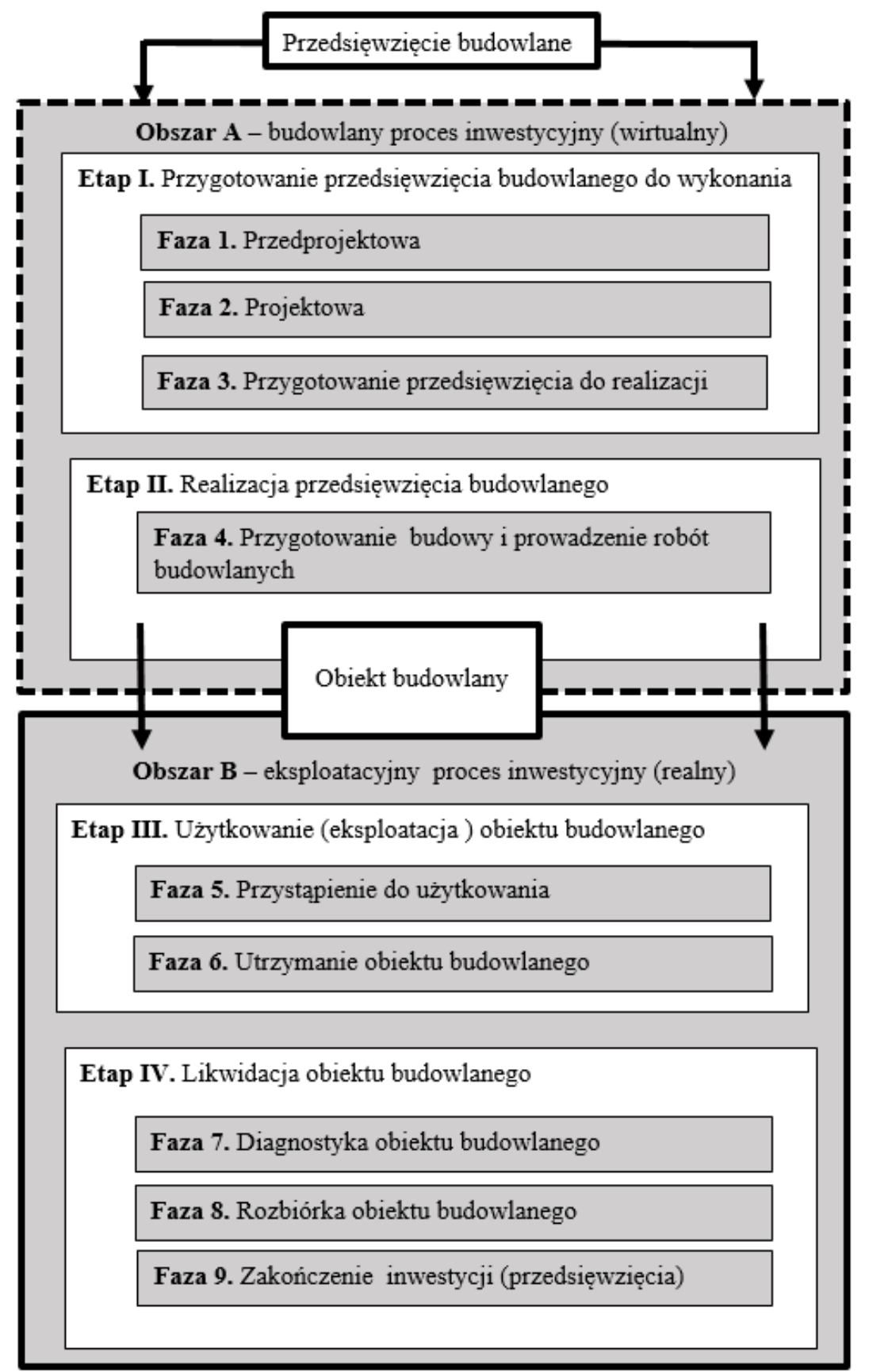

Rys. 1. Model procesu realizacji przedsięwzięcia budowlanego (19)

W Polsce istnieje unormowanie prawne regulujące przebieg realizacji przedsięwzięcia budowlanego (1). Jest to ustawa, która określa wymagania w projektowaniu, budowie, utrzymaniu i rozbiórce obiektów budowlanych oraz określa udział w tych działaniach organów administracji publicznej $(29,30)$. Proces kreowania modelu przedsięwzięcia polega na dostosowaniu struktury organizacyjnej przedsięwzięcia do celów, zasobów i otoczenia. Uczestniczący $\mathrm{w}$ procesie inwestycyjnym ludzie, traktowani jako podmioty procesu inwestycyjnego w budownictwie, występują w różnych (bezpośrednich i pośrednich) rolach. Bezpośrednimi uczestnikami według prawa budowanego są: inwestor inspektor nadzoru 
budowlanego, projektant, kierownik budowy / kierownik robót oraz zarządca i właściciel obiektu budowlanego.

Inwestorem może być osoba prawna lub inna jednostka organizacyjna odpowiadająca warunkom obowiązującego prawa oraz osoba fizyczna. Rozróżnia się inwestorów państwowych, spółdzielczych, społecznych, czy też prywatnych. W każdym przypadku inwestor reprezentuje w procesie inwestycyjnym zapotrzebowanie na obiekt budowlany oraz dysponuje środkami finansowymi na inwestycję budowlaną. Zakres udziału inwestora w procesie jest bardzo duży. Obowiązki i prawa inwestora są określone prawem budowlanym i zapewniają mu możliwość odgrywania ważnej roli w sprawach projektowania i prowadzenia robót budowlanych.

Inspektor nadzoru inwestorskiego może zostać powołany z woli inwestora lub może zostać ustanowiony obligatoryjnie, w przypadku szczególnie skomplikowanych prac, budynków użyteczności publicznej lub takich, które mogą mieć negatywny wpływ na środowisko naturalne. Obowiązek jego powołania może być również nałożony na inwestora w decyzji o pozwoleniu na budowę. Inwestor ma również prawo - mimo braku takiego nakazu w decyzji - inspektora powołać pomimo braku takiego nakazu.Do głównych obowiązków inspektora na terenie budowy należy kontrola realizowanych prac pod kątem projektu budowlanego, pozwolenia na budowę, zgodności z zasadami wiedzy technicznej oraz wszelkimi przepisami prawnymi. Inspektor odpowiedzialny jest również za jakość materiałów budowlanych oraz wykonywanych prac. Bierze także udział w próbach i odbiorach technicznych wszystkich instalacji oraz robót ulegających zakryciu i zanikających.

Do obowiązków osoby pełniącej funkcję inspektora należy również przekazywanie gotowych obiektów do użytkowania, potwierdzanie wykonania prac, udział przy usuwaniu ewentualnych wad oraz kontrola rozliczenia budowy.

Projektant wykonuje projekt budowlany na zamówienie inwestora. Mogą się tego podjąć państwowe lub prywatne biura projektowe oraz inne organizacje projektowe. Kształtują one techniczne, ekonomiczne i funkcjonalne rozwiązania dotyczące obiektu budowlanego i mają wpływ na sposób realizacji projektu przez wykonawcę robót budowlanych poprzez instytucję nadzoru autorskiego.

Kierownik budowy / kierownik robót jest wykonawcą robót budowlanych, który ma bezpośredni wpływ na realizację obiektu budowlanego, jego organizację, koszty, postęp techniczny w wykonawstwie, warunki bezpieczeństwa dla ludzi mienia i środowiska w toku prowadzenia robót. Do podstawowych obowiązków kierownika budowy należy: 
— zabezpieczenie i ogrodzenie terenu budowy oraz umieszczenie w widocznym miejscu tablicy informacyjnej, dotyczącej inwestycji, która ma być postawiona na danym miejscu,

— nadzorowanie pracyna budowie tak, aby była ona zgodna z projektem oraz pozwoleniami na budowę,

— prowadzenie pełnej dokumentacji robót,

— podjęcie decyzji o wstrzymaniu prac, jeżeli uzna on, że zaistniało niebezpieczeństwo dla pracowników (musi on o tym fakcie poinformować inwestora).

Właściciel i zarządca obiektu budowlanego nie bierze udziału w procesie projektowania i wznoszenia obiektu, ale ma obowiązek użytkowania tego obiektu zgodnie z przeznaczeniem oraz utrzymywania go w należytym stanie w celu ochrony przed zniszczeniem zapewniając jego bezpieczną eksploatację lub użytkowanie.

Podmioty pośrednie procesu inwestycyjnego w budownictwie to organy administracji architektoniczno-budowlanej i nadzoru budowlanego, które administrują i sprawują nadzór nad budownictwem oraz inspekcje kontrolujące zasoby budowlane na budowie, w tym inspekcje kontrolujące warunki pracy, urzędy dozoru technicznego kontrolujące maszyny i urządzenia techniczne oraz inspekcje sanitarne kontrolujące warunki higieny pracy oraz organizacje społeczno-zawodowe związane z budownictwem. Prawo budowlane narzuca współdziałanie wszystkich podmiotów uczestniczących w realizacji przedsięwzięcia budowlanego i utrzymaniu tzw. bezpieczeństwa podmiotowego.

Zachowania ludzi - uczestników procesu realizacji przedsięwzięcia budowlanego determinują aktualny i przyszły stan bezpieczeństwa i ochrony zdrowia BIOZ. Kultura BIOZ jest elementem ogólnej kultury organizacji $(8,9)$ i jest traktowana jako jeden ze składników kultury społecznej (11,12,16).Termin „bezpieczeństwo podmiotowe” wiąże się z zachowaniami ludzi, a „kultura” łączy je ze zrozumieniem znaczenia tych zachowań w organizacji. Zależności pomiędzy zachowaniami pracowników a kulturą są ze sobą spójne, ponieważ jedne i drugie są związane z podstawowymi założeniami organizacji w kwestiach bezpieczeństwa. Reguły kulturowego postrzegania i postępowania są kształtowane poprzez zaangażowanie pracowników na rzecz środowiska fizycznego pracy (narzędzia, maszyny, organizacja stanowiska pracy) oraz poprzez zachowania pracowników (przestrzeganie przepisów bhp, przekazywanie informacji, współpraca, troska o bezpieczeństwo wykraczająca poza obowiązki), wynikające z ich cech wewnętrznych takich jak: wiedza, umiejętności, motywacja (10). 
Poziom bezpieczeństwa podmiotowego (człowieka, grupy, organizacji itp.) w ujęciu globalnym zależy dziś od wielu dziedzinowych poziomów bezpieczeństwa, w tym bezpieczeństwa pracy (9). Wymagany poziom bezpieczeństwa i ochrony zdrowia w pracy (BIOZ) można uzyskać na wiele sposobów i wpływać na zachowania ludzi poprzez:

— zapobieganie powstawaniu danego rodzaju zagrożeń,

— przygotowanie podmiotu na wypadek uaktywnienia danego rodzaju zagrożenia (edukacja, rozmieszczenie sił i środków przeciwdziałania, itp.),

— zwiększanie skuteczności sił i środków w przeciwdziałaniu skutkom niebezpiecznego zdarzenia,

— skuteczność działań w usuwaniu następstw niebezpiecznego zdarzenia.

Należy jednak pamiętać, że stan BIOZ nie jest stanem stabilnym. W budownictwie pojawiają się nowe zagrożenia wywołane siłami natury bądź niezamierzoną i/lub zamierzoną działalnością człowieka. Każdy podmiot musi zatem w swoich zachowaniach zadbać o stabilność stanu bezpieczeństwa poprzez przestrzeganie ustalonych zasad, w tym zasad etycznych.

Od uczestników procesu inwestycyjnego w budownictwie wymaga się odpowiednich kompetencji stosownie do wykonywanej pracy. Do podstawowych kompetencji współczesnego pracownika zalicza się kreatywność, komunikatywność, umiejętność współpracy, samodzielność. Brakuje wśród nich tej bezpośrednio związanej z pracą kompetencji etycznej, rozumianej jako znajomość obowiązujących reguł i zasad etycznych, która kształtuje pożądany poziom kultury bezpieczeństwa pracy (26).

\section{Kompetencje etyczne uczestników procesu realizacji przedsięwzięcia budowlanego}

Zainteresowanie sprawami etyki towarzyszy ludzkości od zarania dziejów. Wraz z upływem czasu etyka stara się bronić autentycznego szczęścia ludzi i chronić ich przed zagubieniem w świecie własnej cywilizacji, utratą własnej tożsamości i godności, skłania do troski o bezpieczeństwo własne i innych, bliźnich i przyrody. Ludzie w swojej aktywności kierowali się i kierują pewnymi wartościami, zasadami i regułami, a za skutki tej działalności ponosili i ponoszą odpowiedzialność. Aktywność ich była uzależniona od intelektu, etyki i temperamentu, które miały i mają zasadniczy wpływ na zachowania człowieka.

W literaturze spotyka się różne odmiany etyki, które ze względu na kryterium zajmują się własnymi zagadnieniami (tab.1). 
Tabela 1. Rodzaje etyki ze względu na kryterium podziału

\begin{tabular}{|l|l|l|}
\hline Lp. & Nazwa & \multicolumn{2}{l|}{ Charakterystyka ogólna } \\
\hline Kryterium: sposób podejścia i tradycja rozwoju \\
\hline 1. & $\begin{array}{l}\text { Etyka } \\
\text { normatywna }\end{array}$ & wartościuje, postuluje i argumentuje, czyli odpowiada na pytanie jak być powinno. \\
\hline 2. & Etyka opisowa & $\begin{array}{l}\text { opisuje i wyjaśnia, jakie były lub są obyczaje, zwyczaje i zachowania moralne, } \\
\text { czyli odpowiada na pytanie jak jest lub jak było. }\end{array}$ \\
\hline 3. & Metaetyka & zajmuje się etycznymi problemami o charakterze regionalnym i globalnym. \\
\hline Kryterium: zakres refleksji etycznej \\
\hline 1. & Mikroetyka & zajmuje się relacjami o charakterze etycznym między ludźmi \\
\hline 2. & Makroetyka & zajmuje się etycznymi problemami o charakterze regionalnym i globalnym. \\
\hline 3. & Etyka moralna & $\begin{array}{l}\text { zajmuje się etycznymi problemami ludzi w dowolnej organizacji społecznej, ich } \\
\text { moralnością zawodową i postępowaniem firm. }\end{array}$ \\
\hline $\begin{array}{l}\text { Kryterium: szczegółowość i ogólność podejmowanych problemów moralnych i uzasadnień głoszonych } \\
\text { dyrektyw, norm i zaleceń }\end{array}$ \\
\hline 1. & $\begin{array}{l}\text { Etyka ogólna } \\
\text { jest filozoficzną refleksją nad podstawami etyki takimi jak np. cel, dobro, } \\
\text { powinność, sumienie, odpowiedzialność. }\end{array}$ \\
\hline 2. & $\begin{array}{l}\text { Etyka } \\
\text { szczegółowa }\end{array}$ & $\begin{array}{l}\text { obejmuje etykę indywidualną - normuje życie jednostek ludzkich oraz etykę } \\
\text { społeczną, której adresatem jest społeczna sfera życia. }\end{array}$ \\
\hline 2. & $\begin{array}{l}\text { Etyka biznesu } \\
\text { (bussines ethic) }\end{array}$ & $\begin{array}{l}\text { zajmuje się zagadnieniami moralnymi w działalności gospodarczej, w tym } \\
\text { szczególności formułowaniem zasad i kodeksów postępowania w świecie biznesu. }\end{array}$ \\
\hline
\end{tabular}

Źródło: opracowanie własne na podstawie $(8,12,13,26)$

Poszukując wspólnej definicji etyki można określić ją jakodyscyplinę fillozoficzną, której domeną są normy, oceny i wzorce regulujące stosunki między ludźmi i ich czyny wobec innych ludzi, intencje i motywacje tych czynów oraz ich efekty mające wpływ na zachowania (31). W procesie realizacji przedsięwzięcia budowlanego biorą udział ludzie o różnych poglądach na zagadnienia bezpieczeństwa i ochrony zdrowia w pracy. Niezależnie od przekonań obowiązują ich zasady ustalone dla danego procesu, które wynikają z ogólnoludzkich zasad etycznych.

Ogólnoludzkie zasady etyczne obowiązują każdego człowieka bez względu na stan, wiek, zawód, pozycję, stanowisko i środowisko społeczne, w jakim się znajduje. Bardziej szczegółowe zasady etyczne są formułowane dla określonych rodzajów działalności, np. reklamy, marketingu, zakładów, firm, grup zawodowych np. sędziów, lekarzy, nauczycieli itp.

Treść norm i zobowiązań wymaganych od przedstawicieli danego zawodu, które są ułożone w uporządkowany logicznie zespół wytycznych, tworzą kodeks zachowań. Może to być np. kodeks budowlany $(1,30)$ czy też kodeks lekarski w postaci Kodeksu Etyki Lekarskiej opracowany na podstawie Deklaracji Helsińskiej (7) lub też kodeks etyczny opracowany dla realizowanego projektu / przedsięwzięcia budowlanego. 
Kodeks etyczny przedsięwzięcia budowlanego zawiera normy i zobowiązania wymagane od uczestników, które są ułożone w uporządkowany logicznie zespół wytycznych dotyczących realizowanego przedsięwzięcia. Opracowanie takie jest prezentacją wartości uznawanych za szczególnie cenne, zwierającą przykłady rozwiązań konfliktowych, kształtowanie świadomości i wrażliwości etycznej wszystkich uczestników przedsięwzięcia budowlanego. Jest to szczególnie ważne w przypadku współpracy różnych grup zawodowych wykonujących swoje obowiązki w obszarach, projektowania, wykonawstwa budowlanego i eksploatacji obiektu budowlanego. Należy przy tym pamiętać, że kodeks etyczny dotyczy zarówno zamawiającego / inwestora, wykonawców jak i podmiotów odpowiedzialnych za użytkowanie / eksploatację obiektu budowlanego, którzy podczas realizacji przedsięwzięcia tworzą określoną społeczność, w której obowiązują określone wartości i normy postępowania.

Myślenie kategoriami etycznymi powinno być jednym z istotnych elementów decyzji, które są podejmowane przez uczestników realizacji przedsięwzięcia budowlanego, w którym uwzględnić należy wymagania etyki (aby były dobre),estetyki (aby były piękne),prakseologii (aby były skuteczne),ekonomii, (aby były opłacalne), bezpieczeństwa i ochrony zdrowia (aby były bezpieczne). Uczestnicy przedsięwzięcia stają często wobec dylematów związanych z oceną moralną swoich decyzji związanych np. z opisem przedmiotu zamówienia i wyborem wykonawcy czy z realizacją zamówienia przez wykonawcę (6). Aby decyzja była zgodna z zasadami etyki wymagane są odpowiednie kompetencje etyczne. Kompetencje etyczne są zbiorem opanowanej wiedzy, umiejętności i postaw, które należy wykorzystać w działaniach wszystkich uczestników przedsięwzięcia budowlanego. Do opracowania kodeksu etycznego przedsięwzięcia budowlanego wymagana jest znajomość podstawowych kategorii i zasad etycznych.

Kategorie etyczne oznaczają sądy i orzeczenia, które są podstawowymi pojęciami w etyce. Do najpowszechniejszych pojęć etycznych należą przede wszystkim: wartość, ideał, dobro i zło, sumienie, norma etyczna, norma moralna, obowiązek, sankcja, szczęście, odpowiedzialność. Charakterystykę kategorii etycznych przedstawiono w tab.2. 
Tabela 2. Kategorie etyczne i ich charakterystyka

\begin{tabular}{|c|c|c|}
\hline Lp. & Nazwa & Charakterystyka ogólna kategorii etycznej \\
\hline 1 & Wartość & $\begin{array}{l}\text { To wszystko, co cenne, godne pożądania lub wyboru, co stanowi cel ludzkich } \\
\text { dążeń. Jest to cecha, która może być traktowana pozytywnie (wartość dodatnia, } \\
\text { np. dobro, cnota, zaleta) lub negatywnie (wartość ujemna, np. zło, wada). } \\
\text { Wartością może być to wszystko, co stanowi przedmiot pożądania, dążenia i } \\
\text { aspiracji człowieka, nie ma wartości negatywnych, istnieją tylko antywartości. } \\
\text { Mogą być wartości autoteliczne, czyli takie, których uznanie lub realizacja nie } \\
\text { wymaga innych wartości oraz wartości instrumentalne, czyli takie, które służą } \\
\text { osiąganiu innych, wyższych i bardziej cennych. }\end{array}$ \\
\hline 2 & Ideał & $\begin{array}{l}\text { To wzór moralny stanowi w każdym systemie etycznym całość, którą określają } \\
\text { cele stawiane w życiu i środki ich realizacji. Zawiera on rejestr zalecanych, } \\
\text { moralnie właściwych form działania, przedstawia naturę i istotę oraz powołanie } \\
\text { człowieka. Ideał jest interpretacją pojęć abstrakcyjnych, np. męstwo, } \\
\text { sprawiedliwość, wolność. }\end{array}$ \\
\hline 3 & Dobro i zło & $\begin{array}{l}\text { Pojęcia, które się wzajemnie zaprzeczają. Dobro jest określane w szerszym } \\
\text { znaczeniu czynem (sposobem działania) i jego następstwem (wartością) oraz w } \\
\text { węższym znaczeniu moralnym czynem i postępowaniem (bardziej sposobem i } \\
\text { procedura działania). Pod pojęciem dobra rozumie się najczęściej to, co jest } \\
\text { pożądane oraz to, co pozytywne i stanowiące wartość pozytywną. }\end{array}$ \\
\hline 4 & Sumienie & $\begin{array}{l}\text { Świadomość moralna, która pozwala oceniać wartości moralne czynów oraz } \\
\text { zdolnością reagowania na dobro i zło moralne. Jest to rodzaj predyspozycji do } \\
\text { oceniania swoich i cudzych czynów oraz uczuć związanych z tą oceną. } \\
\text { Sumienie pełni funkcję sędziego, który decyduje o poczuciu zadowolenia lub } \\
\text { winy wynikającej ze spełnionego obowiązku, powinności i czynu. }\end{array}$ \\
\hline 5 & Normy etyczne & $\begin{array}{l}\text { Charakteryzują się tym, że są respektowane bez względu na sankcje zewnętrzne } \\
\text { i są związane z dojrzałością sumienia i osobowości człowieka. Motywem } \\
\text { postępowania etycznego nie jest zewnętrzna nagroda czy kara, ale wartość sama } \\
\text { w sobie, czyli dobro. Sens przestrzegania norm etycznych sprowadza się do } \\
\text { dobrego samopoczucia człowieka, które ma charakter psychologiczny. }\end{array}$ \\
\hline 6 & Normy moralne & $\begin{array}{l}\text { Mają szerszy zakres znaczeniowy niż normy etyczne, obejmują także normy } \\
\text { zwyczajowe, obyczajowe i faktyczne zachowania ludzi poddawane ocenom } \\
\text { etycznym. Normy te występują w formie nakazów lub zakazów oraz dzielą się } \\
\text { na normy etyczne, moralne i poza moralne, czyli głównie religijne i prawne. } \\
\text { Niemniej normy moralne i etyczne, religijne i prawne mogą być nastawione na } \\
\text { chronienie jednych i tych samych wartości, np. nie kradnij lub nie zabijaj. } \\
\text { Normy moralne są związane z określonymi sankcjami grupy społecznej, } \\
\text { wyrażanymi się w opinii jej członków, od grupy członków po opinię publiczna } \\
\text { wspólnoty }\end{array}$ \\
\hline 7 & Obowiązek & $\begin{array}{l}\text { Powinność moralna jest determinacją do wykonania lub zaniechania czegoś, } \\
\text { która wynika z subiektywnie rozpatrywanego nakazu moralnego - etycznego } \\
\text { (głosu wewnętrznego lub głosu sumienia) lub określonej społecznie normy } \\
\text { moralnej (etycznej, zwyczajowej, obyczajowej). }\end{array}$ \\
\hline 8 & Sankcje & $\begin{array}{l}\text { Sankcje mają różnorodny charakter i dzielą się na kary i nagrody. Wyrażają się } \\
\text { w samoocenie człowieka i ocenie społecznej, czyli opinii publicznej. } \\
\text { Samoocena wiąże się z głosem sumienia i wyrzutami sumienia lub spokojem } \\
\text { sumienia. }\end{array}$ \\
\hline 9 & Szczęście & $\begin{array}{l}\text { Pełne, trwałe i uzasadnione zadowolenie z życia lub życie dające trwałe, pełne i } \\
\text { uzasadnione zadowolenie. Szczęście jest dobrem najwyższym w wielu } \\
\text { systemach etycznych, np. Arystoteles identyfikuje szczęście z } \\
\text { samowystarczalnością, a ta z kolei należy się bytom doskonałym i dlatego } \\
\text { dążenie do niej czyni życie godnym pożądania i wolnym od wszelkich braków. }\end{array}$ \\
\hline 10 & Odpowiedzialność & $\begin{array}{l}\text { Polega na gotowości sprawcy czynu moralnego do ponoszenia konsekwencji, } \\
\text { wzięciu na siebie dobrych i złych skutków postępowania. }\end{array}$ \\
\hline
\end{tabular}

Źródło: opracowanie własne na podstawie $(21,22)$. 
Zasady etyczne są najczęściej traktowane jako sposoby osiągania czegoś i stanowią o tym sposobach. Od zasad odróżnialne są reguły, które nakazują określone działanie. Można więc przyjąć, że zasady orzekają a reguły nakazują określone postępowanie i zachowanie.

W literaturze występują różne zasady etyczne. Przykładem mogą być zasady etyki sformułowane przez Feliksa Konecznego (13) takie jak: sumienność, sprawiedliwość, odpowiedzialność, bezinteresowność, obowiązkowość, punktualność (stosunek do czasu) i pracowitość (stosunek do pracy).Charakterystykę ogólną zasad etycznych przestawiono w tab.3.

Tabela 3. Zasady etyczne i ich charakterystyka

\begin{tabular}{|l|l|l|}
\hline Lp. & \multicolumn{1}{|c|}{ Nazwa } & \multicolumn{1}{c|}{ Charakterystyka ogólna zasady etycznej } \\
\hline 1 & Sumienność & $\begin{array}{l}\text { Zasada sumienności opisuje nastawienie do codziennych wyzwań i obowiązków, } \\
\text { a także określa stopień motywacji i zorganizowania. Ten czynnik osobowości } \\
\text { można zbadać za pomocą dwóch zmiennych: planowania oraz elastyczności. Z } \\
\text { jednej bowiem strony, stopień sumienności definiuje nasz sposób organizacji i } \\
\text { radzenia sobie z wyzwaniami, z drugiej zaś decyduje o tym, czy człowiek potrafi } \\
\text { podejmować spontaniczne decyzje i jest elastyczny. }\end{array}$ \\
\hline 2 & Sprawiedliwość & $\begin{array}{l}\text { Bazuje na zasadzie funkcjonowania świata w tym relacji między ludźmi. osoba } \\
\text { starająca się działać sprawiedliwe przykłada do siebie i innych ludzi zawsze tę } \\
\text { samą miarę moralną i stara się w relacjach z nimi postępować zawsze zgodnie z } \\
\text { wyznawanymi przez siebie zasadami etycznymi. }\end{array}$ \\
\hline 3 & Odpowiedzialność & $\begin{array}{l}\text { Obowiązek moralny lub prawny (konieczność) odpowiadania za swoje czyny i } \\
\text { ponoszenia za nie konsekwencji. }\end{array}$ \\
\hline 4 & Bezinteresownośćc & $\begin{array}{l}\text { Cecha działania podmiotu, przy której celem działania nie jest korzyść podmiotu, } \\
\text { ale dobro innej osoby. }\end{array}$ \\
\hline 5 & Obowiązkowośćc & Poczucie odpowiedzialności za prowadzone działania. \\
\hline 6 & Punktualność & Wykonywanieczegośwściśleokreślonymczasie; umiejętnośćniespóźniania się. \\
\hline 7 & Pracowitość & Chęć do pracy, zamiłowanie do pracy, wytrwałość podczas wykonywania prac. \\
\hline
\end{tabular}

Źródło: opracowanie własne na podstawie $(13,18,22)$.

\section{Bezpieczeństwo pracy i ochrony zdrowia w etyce zawodowej}

Aspekt etyki w zawodzie nazywany jest potocznie etyka zawodowa. Etykę zawodową tworzą zbiory norm postępowania przedstawicieli danego zawodu w postaci kodeksów, przysięg, ślubowań czy zobowiązań. Uczestnikami przedsięwzięcia budowlanego są przedstawiciele różnych zawodów, zatem etykę zawodową procesu należy budować w oparciu o wartości etyczne grup zawodowych biorących udział w przedsięwzięciu budowlanym tworząc $\mathrm{w}$ ten sposób wspólny mianownik dla wszystkich. Jest to zadanie złożone i trudne do zrealizowania. W każdym zawodzie powinny być analizowane zagadnienia, które mają wpływ na bezpieczeństwo pracy i ochronę zdrowia i życia pracowników. Termin „bezpieczeństwo” wiąże się z zachowaniem ludzi realizujących przedsięwzięcie budowlane, i z „kulturą” łącząc zrozumienie znaczenia tych zachowań 
w procesie realizacji przedsięwzięcia. Zależności pomiędzy zachowaniami uczestników a kulturą są ze sobą spójne, ponieważ jedne i drugie są związane $\mathrm{z}$ podstawowymi założeniami $\mathrm{w}$ kwestiach etycznych bezpieczeństwa pracy $\mathrm{w}$ procesie realizacji przedsięwzięcia budowlanego. Reguły kulturowego postrzegania i postępowania są kształtowane poprzez zaangażowanie ludzi na rzecz środowiska pracy (narzędzia, maszyny, organizacja pracy) oraz poprzez zachowania pracowników (przestrzeganie przepisów bhp, przekazywanie informacji, współpraca, troska o bezpieczeństwo wykraczające poza obowiązki), wynikające $\mathrm{z}$ ich cech wewnętrznych takich jak: wiedza, umiejętności, motywacja, stosunek do pracy(19).

W polskiej praktyce budowlanej zauważa się, że bezpieczeństwo pracy staje się integralną częścią funkcjonowania przedsiębiorstwa i chroni pracę, a poza tym ma zasadniczy wpływ na wynik ekonomiczny oraz na zachowania pracowników (27). W literaturze ochronę pracy definiowano jest jako całokształt norm prawnych oraz środków badawczych, organizacyjnych i technicznych mających na celu ochronę życia i zdrowia pracownika przed czynnikami niebezpiecznymi i szkodliwymi w środowisku pracy, a także stworzenie mu optymalnych warunków z punktu widzenia ergonomii, fizjologii i psychologii pracy wzajemnie ze sobą powiązanych (15). Natomiast bezpieczeństwo i higiena pracy potraktowano jako ogół norm prawnych oraz środków badawczych, organizacyjnych i technicznych mających na celu stworzenie pracownikowi takich warunków pracy, aby mógł on wykonywać pracę w sposób produktywny, bez narażania się na nieuzasadnione ryzyko wypadku lub choroby zawodowej oraz nadmierne obciążenie fizyczne i psychiczne (14).

$\mathrm{Z}$ teoretycznego punktu widzenia problematyka bezpieczeństwa pracy i ochrony zdrowia $\mathrm{w}$ trakcie realizacji przedsięwzięcia budowlanego wpisuje się w kompetencje etyczne (moralne) uczestników przedsięwzięcia. Jednak analiza ekonomiczna przedsięwzięcia budowlanego kłóci się z wymogiem moralnym, generuje bowiem zwiększenie kosztów całegoprzedsięwzięcia. Powstaje w ten sposób dylemat etyczny dla uczestników procesu - jak pogodzić jednocześnie powinności takie jak:

— konieczność chronienia zdrowia i życia pracowników / uczestników przedsięwzięcia,

- przestrzeganie przepisów prawa pracy, realizowanie polityki bhp,

— sprostanie oczekiwaniom poszczególnych pracodawców,

- ekonomikę przedsięwzięcia budowlanego,

— uwzględnianie autonomii poszczególnych uczestników przedsięwzięcia. 


\section{Podsumowanie}

Dobrym rozwiązaniem wydaje się opracowanie dla procesu realizacji przedsięwzięcia budowlanego wspólnego kodeksu postępowania obowiązującego wszystkich uczestników procesu, w którym znajdzie się miejsce na aspekt etyczny. Dokument taki powinien zawierać podstawowe zasady i wartości obowiązujące inwestora, projektantów, wykonawców robót budowlanych oraz właścicieli i zarządców, w którym zakłada się transparentność działań, dbałość o wartości etyczne, ochronę życia i zdrowia pracowników, tworzenie przyjaznej atmosfery pracy i wzajemną otwartość i koordynację działań. Kodeks postępowania zaakceptowany przez wszystkich uczestników procesu realizacji inwestycji powinien stanowić integralną częścią umów podpisywanych pomiędzy nimi.

\section{Literatura}

[1] Bar L., Kodeks budowlany. Przepisy i wyjaśnienia, Wydawnictwo Prawnicze, Warszawa 1972, 1109s.

[2] Baryłka A., Basic of Engineering S of Antropogenic Object Safety, Inżynieria Bezpieczeństwa Obiektów Antropogenicznych nr 1/2015, 2015, s.10-16

[3] Baryłka A., Okresowe kontrole obiektów budowanych w procesie eksploatacji, ISBN 978-83-944607-7-8, 2018, 628s.

[4] Baryłka A., Poradnik rzeczoznawcy budowlanego. Tom I - Problemy technicznoprawne diagnostyki obiektów budowlanych, ISBN 978-83-944607-5-4, 2018, s.658

[5] Baryłka A.,Propedeutics of safety engineering of anthropogenic objects, Modern Engineering, Rocznik 1/2017, art.4

[6] Błachut K., Nikitiuk H., Nowak B., Rybka J., Tiukało A., Przedsięwzięcie budowlane. Poradnik inwestora, Grupa Wydawnicza Marciszewski, Wrocław 2007, 234s.

[7] Deklaracja Helsińska Światowego Stowarzyszenia Lekarzy, Edynburg, 2000

[8] Ejdys J., Kształtowanie kultury bezpieczeństwa i higieny pracy w organizacji, Oficyna Wydawnicza Politechniki Białostockiej, Białystok, 2010

[9] Europejska Komisja dział 4 (2011), Niewiążący podręcznik dobrych praktyk na potrzeby zrozumienia i wdrożenia dyrektywy 92/57/EWG „budowy”, Luksemburg Unia Europejska, 2011

[10] Geller E. S., The psychology of safety, Chlinton Book Company, Radmor, Pensylvania, 1996 
[11] Glend A. I. Stanton N.A., Perspetives of safety culture, Safety Science, vo. 34 no 1-3, 2000

[12] Guldenmund F., The nature of safety culture: a review of theory and research, Safety Science 2000 vol.34, no1-3

[13] Koneczny F., Etyki a cywilizacje, Dom Wydawniczy Ostoja, 2004

[14] Kowalski J., Krzyśków B., Procesy pracy, pojęcia podstawowe, geneza idei ochrony pracy, Nauka o pracy - bezpieczeństwo, higiena, ergonomia, red. naukowa D.

Koradecka, Wyd. Centralny Instytut Ochrony Pracy, 2000, Warszawa, s.13

[15] Kowalski J., Podstawy prawne ochrony pracy w Polsce, w: Bezpieczeństwo pracy i ergonomia, red. Nauk. D. Koradecka, Warszawa, CIOP, 1999, s.643

[16] Mearns K.J., Flin R., Assessing the state of organizational safety - culture or climate? CurrentPsychology, vol. 18 no 1/1999

[17] Obolewicz J., Bezpieczeństwo pracy w budownictwie, Wyd. Unimedia, 2012, 254s.

[18] Obolewicz J., Culture of work safety in the implementation of antropogenic, construction objects, Inżynieria Bezpieczeństwa Obiektów Antropogenicznych nr 4/2016, 2016, s.10-14

[19] Obolewicz J., Demoskopia bezpieczeństwa i ochrony zdrowia przedsięwzięć budowlanych, Oficyna Wydawnicza Politechniki Białostockiej, Białystok 2018, 184s.

[20] Obolewicz J., Koordynacja bezpieczeństwa i ochrony zdrowia w budowlanym procesie inwestycyjnym, w: Przegląd budowlany nr 2/2011, 2011, s. 60-63

[21] Obolewicz J., Kultura bezpieczeństwa pracy i zdrowia zawodowego w organizacji: [rozdz. w:]Badania naukowe Wszechnicy Mazurskiej w Olecku, Wyd. WszechnicyMazurskiej, Episteme 70/2007, 2007, s.59-69

[22] Obolewicz J., Problemy kształtowania kultury bezpieczeństwa i ochrony zdrowia na budowie, Praca i Zdrowie nr 9/2011, 2011, s. 22-26

[23] Obolewicz J., Wybrane aspekty bezpieczeństwa i ochrony zdrowia przedsięwzięć budowlanych, Modern Engineering, Rocznik 1/2018, art.1

[24] Rozporządzenie Ministra Infrastruktury z dnia 6 lutego 2003 r. w sprawie bezpieczeństwa i higieny pracy podczas wykonywania robót budowlanych

[25] Rychta D., Ocena techniczna istniejącego budynku użyteczności publicznej w kontekście jego dalszej eksploatacji oraz nowych zamierzeń budowlanych na przykładzie budynku przedszkola, Modern Engineering, Rocznik 1/2016, s.40-52 
[26] Sadłowska-Wrzesińska J., Gruszka J., Kompetencja etyczna - kluczowy element projakościowych aspektów zarzadzania bezpieczeństwem pracy, Zeszyty Naukowe Politechniki Poznańskiej nr 72, Organizacja i zarządzanie, 2017, s.187-198

[27] Szruba M., Bezpieczeństwo w budownictwie, nr Styczeń - luty 2017, Nowoczesne Budownictwo Inżynieryjne, 2017, s.23-25

[28] Szymanik T, Janczarek G., Zagrożenia eksploatacyjne w budownictwie (promieniowanie, mikroklimat, degradacja materiałów( art. 1), Inżynieria Bezpieczeństwa Obiektów Antropogenicznych nr 3-4/2018

[29] Ustawa z dn. 7 lipca 1994r. Prawo budowlane

[30] Ustawa z dnia 26 czerwca 1974 roku Kodeks pracy

[31] Wołk Z., Zadania pedagogiki pracy wobec zmian współczesnego świata. Pedagogika Pracy $n r$ 42, 2003, s.57-67 